\title{
Arkadiusz Kwapisz
}

Urząd Patentowy Rzeczypospolitej Polskiej

e-mail: Arkadiusz.Kwapisz@uprp.gov.pl

\section{SYSTEM DO ZARZĄDZANIA DOKUMENTACJĄ PATENTOWĄ W WYSZEHRADZKIM INSTYTUCIE PATENTOWYM}

\section{SYSTEM FOR MANAGING PATENT \\ DOCUMENTATION IN VISEGRAD PATENT INSTITUTE}

DOI: 10.15611/ie.2018.4.05

JEL Classification: D83, K10, M12

Streszczenie: W artykule przedstawiono system do zarządzania dokumentacją patentową w Wyszehradzkim Instytucie Patentowym (VPI) pełniącym funkcję Międzynarodowego Organu Poszukiwań (ISA) i Międzynarodowego Organu Badań Wstępnych (IPEA). Zadaniem systemu jest obliczanie terminów na sporządzenie międzynarodowego raportu i opinii wstępnej oraz przydzielenie zespołu ekspertów do sprawy. Każdy z ekspertów wyznaczony w danej sprawie otrzymuje informacje o przydzielonej sprawie, w szczególności o terminach, w których powinien wykonać raport międzynarodowy i opinię wstępną. Dane prezentowane są na zmodyfikowanym wykresie Gantta. Jeśli termin się zbliża, wyznaczeni eksperci otrzymują odpowiednie powiadomienia wysyłane e-mailem. Dotychczasowy system nie miał takiej funkcjonalności. Omawiany system stanowi jedynie archiwum przechowujące zbiory plików.

Słowa kluczowe: wykres Gantta, zarządzanie dokumentacją, patent, Wyszehradzki Instytut Patentowy.

Summary: The article presents a system for managing patent documentation at the Visegrad Patent Institute (VPI) acting as the International Search Authority (ISA) and the International Preliminary Examining Authority (IPEA). The system's task is to calculate deadlines for preparing an international report and preliminary opinion, and assigning a team of experts to the application. Each of the experts appointed in a given case receives a number of information about the assigned case, in particular about the dates in which it should perform an international report and written opinion. The data is presented on a modified Gantt chart. In the case of deadlines, designated experts receive appropriate notifications in the form of e-mail. The previous system did not have such functionality. It is only an archive that stores files.

Keywords: Gantt chart, document management, patent, Visegrad Patent Institute, e-mail notification. 


\section{Wstęp}

Urząd Patentowy Rzeczypospolitej Polskiej działa jako urząd przyjmujący zgłoszenia PCT. Zgłoszenia międzynarodowe z wyznaczeniem Wyszehradzkiego Instytutu Patentowego (VPI) jako ISA (Międzynarodowy Organ Poszukiwań - International Search Authority) wpływają do urzędu pełniącego funkcje urzędu przyjmującego (RO - Receiving Office) w formie zarówno papierowej, jak i elektronicznej i przekazywane są do Wydziału Zgłoszeń Międzynarodowych w Departamencie Zgłoszeń, gdzie zakładane są akta. Po przeprowadzeniu badania formalnego RO nadaje międzynarodowy numer zgłoszenia i międzynarodową datę zgłoszenia, a następnie tzw. egzemplarz rejestracyjny (record copy) przekazywany jest do Biura Międzynarodowego Światowej Organizacji Własności Intelektualnej (WIPO) za pośrednictwem platformy ePCT. Po wniesieniu przez zgłaszającego stosownych opłat upoważniony pracownik wysyła tzw. egzemplarz do celów poszukiwań (search copy) do wyznaczonego organu poszukiwań, a także zalicza odpowiednio opłaty i wydaje dyspozycję do biura finansowego o przekazaniu opłat do organów międzynarodowych (WIPO oraz ISA/XV lub ISA/EPO).

Departament Badań Patentowych (DP), działający jako Międzynarodowy Organ Poszukiwań (ISA), otrzymuje podanie (request) oraz egzemplarz do celów poszukiwań z urzędu przyjmującego (RO) lub pobiera je z platformy ePCT. ISA zakłada akta sprawy.

ISA oczekuje na otrzymanie z sekretariatu VPI lub z platformy ePCT informacji o wpłynięciu opłaty za wykonanie raportu i opinii wstępnej. Po otrzymaniu potwierdzenia otrzymania opłaty i po przekazaniu sprawy do ISA ISA wysyła informację na formularzu PCT/ISA/202 o otrzymaniu egzemplarza do celów poszukiwań (search copy) do zgłaszającego i biura międzynarodowego oraz powiadamia o tym RO, jeżeli Międzynarodowy Organ Poszukiwań nie jest urzędem przyjmującym.

Zgodnie z zasadą 42.1, 43bis.1 Regulaminu PCT ISA sporządza ISR (International Search Report) (lub jeśli nie jest to możliwe, uzasadnia, dlaczego badanie nie może być wykonane) i opinię pisemną WO (Written Opinion) w terminie:

- 3 miesięcy od daty przekazania search copy do ISA lub

- 9 miesięcy od daty pierwszeństwa zgłoszenia

w zależności od tego, który z nich upływa później.

Gdy zgłaszający nie zastrzega pierwszeństwa, ISA sporządza ISR w terminie 9 miesięcy od daty międzynarodowego zgłoszenia.

Z przedstawionych informacji wynika, że przy obliczaniu terminu na sporządzenie ISR/WO niezbędne są trzy daty, mianowicie:

1) data pierwszeństwa,

2) data zgłoszenia międzynarodowego,

3) data przekazania search copy do ISA. 


\section{Ogólne cele}

\subsection{Stan przed wprowadzeniem systemu}

Obliczanie terminów na sporządzenie ISR/WO oraz przydzielenie zespołu ekspertów do sprawy było nadrzędnym zadaniem, które należało wykonać, aby dotrzymać ustawowych terminów. Wszystkie zgłoszenia międzynarodowe PCT, w których Wyszehradzki Instytut Patentowy został wyznaczony jako Międzynarodowy Organ Poszukiwań, były i są wprowadzane do systemu EZD (Elektroniczne Zarządzanie Dokumentacją) przeznaczonego do zarządzania sprawami zgłoszeń krajowych i do wysyłki elektronicznej. Ze względu na niedogodności tego systemu nie było możliwe wyliczenie dat do sporządzenia ISR/WO i przedzielenie ekspertów. System ten nie miał pól, w których możliwe jest wprowadzenie dat (tj. daty zgłoszenia, daty pierwszeństwa, daty przekazania search copy do ISA) czy też imion i nazwisk ekspertów przydzielonych do sprawy. Brak tych podstawowych pól i powiązanych z nimi funkcjonalności uniemożliwiał procedowanie w ramach VPI. Możliwe było jedynie dodanie notatki informującej o tym, że w aktualnej sprawie zostały wyznaczone dwie osoby. Ekspert, który uruchamiał system EZD, nie otrzymywał informacji dotyczącej przydzielonych mu zadań. Aby ustalić, w jakiej sprawie został przydzielony, powinien otworzyć każdą sprawę i zajrzeć do notatki. Jeśli figurował w notatce, powinien następnie otworzyć wniosek, odczytać daty i samemu obliczyć termin na sporządzenie ISR/WO.

W związku z tymi niedogodnościami konieczne było przygotowanie takiego systemu informatycznego, który tuż po uruchomieniu poinformowałby eksperta, co dokładnie powinien wykonać i w jakiej kolejności.

\subsection{Potrzeba informatyzacji}

Celowe stało się wprowadzenie systemu, który będzie informował ekspertów o tym, do jakich zadań zostali przydzieleni oraz z kim i w jakim terminie powinni je wykonać. Te zadania były nadrzędne względem realizacji procedur VPI $i$, jak się potem okazało, były początkiem powstania VPI Data. VPI Data w wersji v.1.0 został uruchomiony w listopadzie 2016 r. System ten działa do dziś w wersji v.1.15.

\subsection{Struktura systemu}

System zarządzania zawiera następujące elementy:

a) VPI Data,

b) VPI Interactive Chart.

Wymienione elementy współpracują ze sobą. Wymianę danych między nimi zapewniają odpowiednie moduły do zapisu i odczytu plików z rozszerzeniem xml. Strukturę systemu przedstawiono na rys. 1. 


\section{WORKLIST}

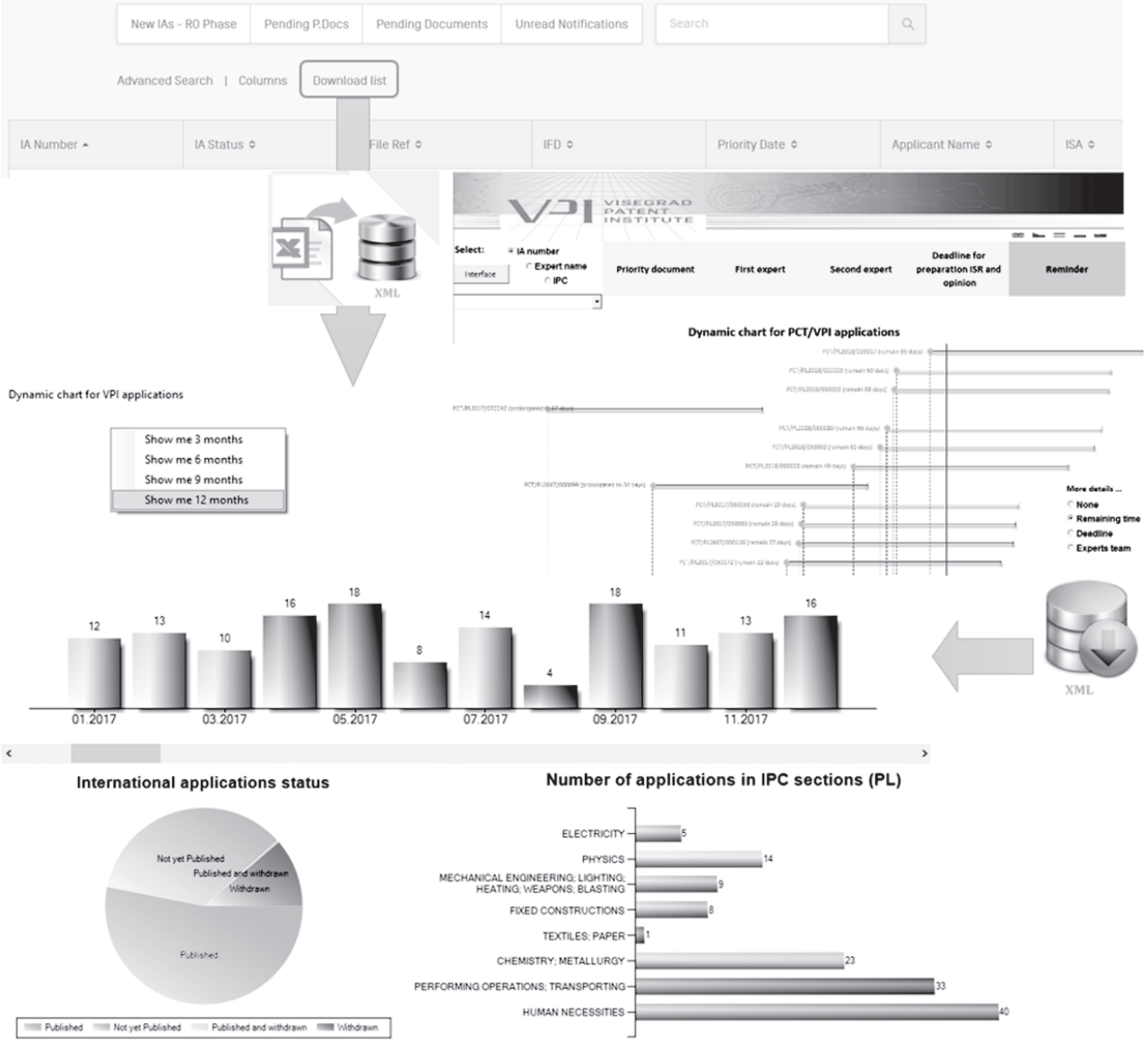

Rys. 1. Struktura systemu zarządzania

Źródło: opracowanie własne.

Podstawowym dostawcą danych jest system ePCT, z którego pobiera się wszystkie informacje dotyczące zgłoszeń PCT. Dane można pobrać bezpośrednio ze sprawy lub z eksportu ePCT. System ePCT zapewnia eksport do pliku ePCT export.xls, który następnie, poprzez konwerter dostępny w VPI Interactive Chart, zamienia plik na ePCT export.xml wykorzystywany do generowania statystyk. VPI Data zapewnia eksport do pliku VPI export.xml bezpośrednio z poziomu interfejsu użytkownika, który również jest wykorzystywany do generowania statystyk. 


\subsection{Struktura programu VPI Data}

Strukturę programu VPI Data zaprezentowano na rys. 2.

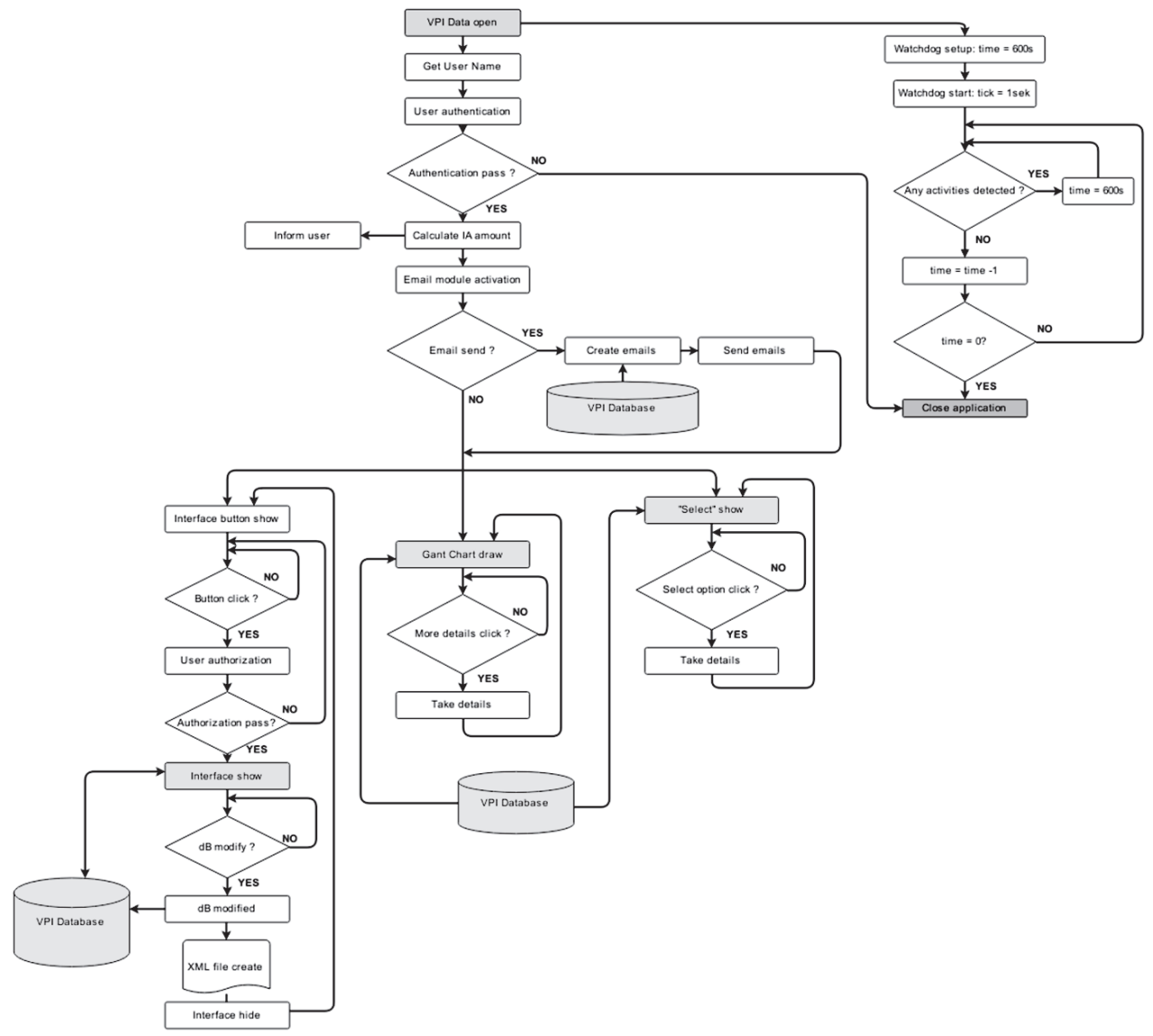

Rys. 2. VPI Data - uproszczona struktura programu

Źródło: opracowanie własne.

Program VPI Data po starcie identyfikuje użytkownika (get user name), a następnie przeprowadza proces uwierzytelniania (user authentication). Gdy uwierzytelnianie nie zostanie zakończone pomyślnie, aplikacja kończy pracę (close application). Jeśli uwierzytelnianie zakończone jest pomyślnie, wywołuje moduł (calculate IA amount) odpowiedzialny za wyliczenie liczby spraw przydzielonych do eksperta. Ekspert zostaje poinformowany (inform user), że aktualnie została mu przydzielona określona liczba spraw do wykonania. Dzięki temu ekspert nie musi zaglądać w systemie EZD do każdej sprawy i sprawdzać, czy w notatce nie występuje jego imię i nazwisko. 
Jednocześnie uruchamia się moduł Watchdog z określonymi parametrami, tj. czasem wynoszącym 600 sekund i tickiem równym sekundzie. Jeśli użytkownik nie korzysta z programu, moduł zmniejsza parametr time o jeden dokładnie co sekundę. Kiedy parametr time osiągnie wartość równą zeru, moduł zamyka aplikację. Jeśli użytkownik korzysta z aplikacji, wartość parametru time jest ustawiana na 600 sekund po każdej wykonanej czynności. Następnie uruchamia się moduł Email (email module activation). Moduł ten pobiera dane $\mathrm{z}$ bazy danych i jeśli stwierdzi, że konieczne jest wysłanie powiadomienia o ubiegającym terminie, tworzy email (e-maile) i wysyła go (je) do użytkownika bądź użytkowników. Następnie uruchamiają się trzy kolejne moduly: Interface show, Gant chart show i Select show.

Dostęp do modułu interfejsu możliwy jest tylko po pomyślnym ukończeniu procesu autoryzacji użytkownika. Kiedy użytkownik ma prawa do modyfikacji bazy danych, może wprowadzić, zmienić lub usunąć dane. Po wprowadzeniu jakichkolwiek zmian w bazie danych moduł kreatora XML tworzy plik VPI export.xml w określonej lokalizacji. Rozpoczyna się nanoszenie danych na wykres z użyciem modułu Gant chart show. Rodzaj danych na wykresie zależy od wyboru (more details), jakiego dokonał użytkownik. Przykładowo, jeśli wybrał opcję Expert team, na wykresie pojawiają się imiona i nazwiska ekspertów przydzielonych do wykonania określonego zadania. Następnie pojawia się narzędzie Select, które również pokazuje wiele różnych informacji związanych z zarządzaniem w VPI. Przykładowo, jeśli użytkownik wybierze opcję Expert name, wyświetla się liczba spraw aktualnie przypisanych do eksperta. Dzięki temu przy wyznaczaniu kolejnych osób do wykonania zadania można uniknąć nadmiernego obciążenia eksperta.

\subsection{Sposób tworzenia programu}

System VPI Data, oraz współpracujące z nim programy, tworzony był etapowo. Początkowo był to niewielki plik Excela z tabelką, w której przechowywane były zgłoszenia patentowe, tj. numery zgłoszeń, daty, symbole klasyfikacji. Kiedy zaszła potrzeba automatycznego wyznaczenia terminów, ze względu na rosnącą liczbę zgłoszeń wprowadzono formuły dla poszczególnych rekordów tak, aby po wprowadzeniu odpowiednich dat możliwe było automatyczne wyznaczenie terminów na sporządzenie ISR/WO. Powstał wykres, który pokazywał podstawowe informacje dotyczące międzynarodowych zgłoszeń patentowych. Z czasem wykres pokazywał coraz więcej informacji. Po krótkim czasie okazało się, że formuły Excela nie są wystarczające do wykonywania terminowych zadań. W związku z tym zaszła konieczność przygotowania dodatkowych funkcji, których nie było w formułach, m.in. takich jak wysyłanie e-maili. Tak rozpoczęła się stopniowa aktualizacja VPI Data z użyciem Visual Basica.

Visual Basic (VB), podobnie jak język programowania BASIC, zaprojektowano $\mathrm{z}$ myślą o łatwej nauce. Programiści mogą tworzyć proste i złożone graficzne aplikacje użytkownika GUI. Programowanie w VB jest kombinacją wizualnie aranżujących komponentów lub formantów w formularzu, określających atrybuty 
i działania dla tych komponentów oraz umożliwiających pisanie dodatkowych linii kodu w celu zapewnienia większej funkcjonalności. Ponieważ Visual Basic definiuje domyślne atrybuty i akcje dla komponentów, programista może opracować prosty program bez pisania wielu linii kodu. Dodatkowo środowisko programistyczne VB wyposażono w symulator kodu, co umożliwia symulację pracy krokowej i ustawienie breakpointów, czyli miejsc, w których program ma się zatrzymać, aby móc np. podejrzeć wartości zmiennych.

Na rysunku 3 przedstawiono pracę krokową programu VPI Data. Po ustawieniu breakpointa, uruchomieniu aplikacji i naciśnięciu CommandButton1, program zatrzymał się na pętli warunkowej if. Pod kontrolą debuggera możliwa jest praca krokowa. Jak widać, można zatrzymać program w dowolnym momencie i kontrolować zmienne, co ułatwia programowanie. Do zmiennej lokalnej sValue typu String przypisano ciąg znaków o postaci 2018.

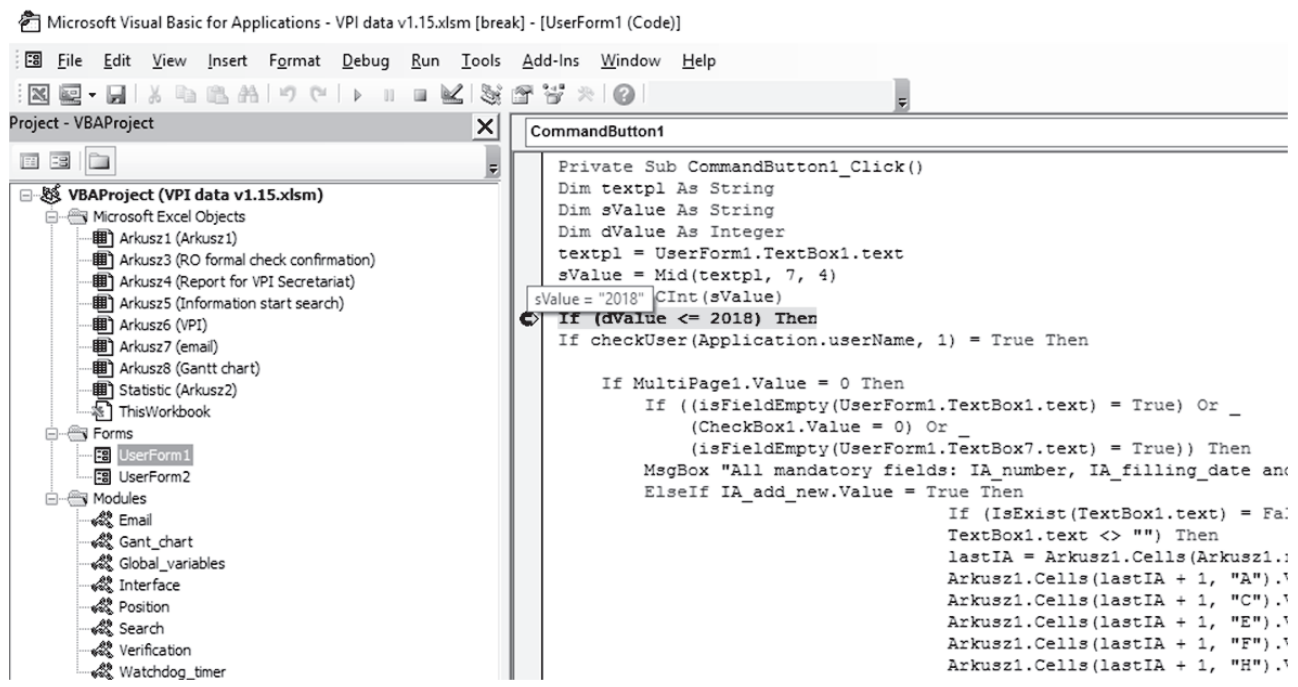

Rys. 3. VBA - praca krokowa programu VPI Data

Źródło: opracowanie własne.

Obecnie VPI Data zapisany jest w jednym pliku, co wyróżnia go wśród systemów sieciowych. Stanowi on pożyteczne narzędzie współpracujące z innymi aplikacjami w celu zarządzania dokumentacją patentową w Wyszehradzkim Instytucie Patentowym. 


\subsection{Niedostatki i plany rozwoju}

Najważniejsze dane znajdują się w kolumnach:

a) IA number - numer zgłoszenia międzynarodowego,

b) IFD - data zgłoszenia międzynarodowego,

c) priority date - data pierwszeństwa.

Dane te nie są wystarczające do obliczenia daty na sporządzenie ISR/WO, gdyż brakuje kolumny SCS (Search Copy Sent to ISA). Urząd Patentowy RP (UPRP) złożył wniosek do WIPO o modyfikację pliku eksportu o dodanie kolumny z datą przekazania search copy do ISA. Dodatkowo UPRP złożył wniosek do WIPO o dodanie kolumny o nazwie Nationality, aby możliwe było automatyczne zidentyfikowanie narodowości zgłaszającego bez konieczności ręcznego odczytu pliku o nazwie Request.

Aktualnie datę przekazania search copy do ISA oraz pozostałe daty wpisuje się ręcznie, co utrudnia automatyzację procesu aktualizacji danych. W przypadku poprawy pliku eksportu o zaproponowane sugestie konieczne będzie zaktualizowanie modułu zaciągania danych do bazy VPI. Dzięki temu możliwe będzie w pełni automatyczne obliczenie wszystkich dat po zaciągnięciu pliku eksportu na aktywny obszar interpretera metodą drag\&drop.

Dodatkowo, tuż po starcie, system powinien również podać nie tylko, ile spraw przydzielono ekspertowi, ale również to, jakie są to sprawy i z kim powinien je wykonać. Przy dużej liczbie spraw, ekspert musi szukać swojego imienia i nazwiska, co jest męczące zwłaszcza w sprawach, które nie są widoczne na wykresie. Dodanie odpowiednich funkcji do modułu wyświetlającego dane powinno rozwiązać ten problem.

\subsection{Twórca systemu}

Wszystkie elementy systemu, tj. VPI Data i VPI Interactive Chart, wykonał autor niniejszego artykułu. Program VPI Data przygotował on w całości w środowisku Visual Basic, natomiast program VPI Interactive Chart - w środowisku.NET C\#. Wszystkie elementy są przez niego stopniowo rozwijane w zależności od potrzeb.

\subsection{Cel artykułu}

Celem artykułu jest przedstawienie nowej koncepcji tworzenia oprogramowania, które pozostaje $\mathrm{w}$ interakcji z użytkownikiem. W odróżnieniu do ogólnie znanych systemów przechowujących dane przedstawiony system prowadzi wirtualny dialog z użytkownikiem, co usprawnia proces zarządzania dużymi ilościami danych. Dane te to przede wszystkim daty, które system przetwarza. Następnie system podejmuje czynności zgodnie z ustalonym algorytmem działania. 


\subsection{Procedura badawcza}

Procedura badawcza obejmowała analizę wszystkich czynności, które powinny być podjęte zgodnie z upływającym czasem. Początkowo analizie poddawano wykresy czasowe, na których naniesiono znaczniki informujące o konieczności podjęcia danej czynności. Do takiej czynności należały powiadomienia określonych użytkowników i wygenerowanie treści zgodnie z ustalonym szablonem. W fazie końcowej procedury badawczej zdefiniowano wszystkie zależności dotyczące powiadomień.

\subsection{Metodyka badania}

Badania przygotowanych algorytmów polegały na przygotowaniu danych testowych i wprowadzeniu ich do systemu. Wszystkie znaczniki informujące o konieczności podjęcia danej czynności były znane. Gdy system wygenerował określone powiadomienie w czasie o określonej treści, stwierdzano, że definicja funkcji jest poprawna. W innym przypadku modyfikowano definicję funkcji odpowiedzialnej za generowanie powiadomień.

\section{VPI Data}

Terminowe wykonywanie sprawozdań i wstępnych opinii wspierane jest przez system informatyczny o nazwie VPI Data, który odpowiedzialny jest za zarządzanie dokumentacją patentową. W procesie uczestniczą odpowiedni ludzie, którym przydzielane są zadania do wykonania z zachowaniem wymaganych terminów. Dzięki jego funkcjonalnościom wykonywanie zadań jest terminowe i odbywa się we właściwej kolejności, co oznacza, że do IB wysyłane są raporty i opinie wstępne, których termin dobiega końca. Zawiera on dwa podstawowe elementy:

- Interfejs z narzędziem wyszukiwawczym Select

Przy użyciu narzędzia wyszukiwawczego Select można wybrać numer zgłoszenia międzynarodowego (IA number), nazwisko i imię eksperta (expert name) oraz wpisać numer Międzynarodowej Klasyfikacji Patentowej (IPC).

- Dynamiczny wykres z narzędziem More details

Dynamicznie zmieniający się wykres przedstawia na bieżąco następujące dane:

- liczbę spraw będących w trakcie rozpatrywania (sprawy przekazane do ISA, sprawy opłacone, ustalony zespół ekspertów); numery spraw są wyświetlane w kolorze zielonym;

- liczbę spraw będących w trakcie rozpatrywania (sprawy przekazane do ISA, opłacone sprawy, w których nie został ustalony kompletny zespół ekspertów i nie minął termin na wykonanie ISR i WO); numery spraw są wyświetlane w kolorze niebieskim;

- liczbę spraw będących w trakcie rozpatrywania (sprawy przekazane do ISA, opłacone, sprawy, w których został ustalony kompletny zespół ekspertów i mi- 
nął termin na wykonanie ISR i WO); numery spraw są wyświetlane w kolorze czerwonym;

- liczbę spraw opłaconych (search fee), ale nieprzekazanych do ISA; numery spraw wyświetlane są na górze wykresu ze stosowną informacją przy wybranej opcji None, tj.: Search fee paid but IA not yet transfered to ISA;

- liczbę dni pozostałych na wykonanie raportu i opinii wstępnej;

- nazwiska i imiona ekspertów przydzielonych do spraw będących w trakcie rozpatrywania.

Narzędzie More details umożliwia wybiórcze przedstawienie określonych informacji na wykresie.

Do podstawowych funkcji systemu należą: przeglądanie zgłoszeń po numerach, sprawdzanie liczby zgłoszeń przydzielonych do eksperta, wyszukiwanie spraw po numerze klasyfikacji oraz wysyłanie różnych wiadomości e-mail zgodnie z podjętą akcją powiadomienia. Wszystkie wiadomości e-mail są wysyłane pod kontrolą użytkownika, co oznacza, że użytkownik aplikacji sprawuje pełną kontrolę nad wysyłaną korespondencją. Dodatkowy moduł powiadamia użytkownika, jaką treść e-maila zamierza wysłać aplikacja, do kogo zamierza go wysłać, jaki będzie jego tytuł. Ostateczna decyzja o wysłaniu e-maila należy do użytkownika, który świadomie potwierdza akcję wysyłki za pomocą przycisku yes - e-mail jest wówczas wysłany, lub odmawia wysłania e-maila za pomocą przycisku no.

\subsection{Watchdog timer}

Moduł ten rozpoczyna swoją pracę w momencie uruchomienia programu i kończy pracę w chwili jego zamknięcia. Moduł jest procesem działającym w tle, a zatem nie jest widoczny dla użytkownika.

\subsection{Weryfikator użytkownika}

Weryfikator użytkownika to moduł odpowiedzialny za identyfikację użytkownika uruchamiającego aplikację. Gdy:

a) użytkownik nie jest pracownikiem Departamentu Badań Patentowych, moduł uniemożliwi uruchomienie aplikacji,

b) użytkownikowi nie przydzielono żadnej sprawy do sporządzenia ISR/WO, moduł poinformuje o tym użytkownika i zamknie aplikację.

Weryfikacja użytkownika nie obejmuje osób uprawnionych do użytkowania aplikacji VPI Data.

\subsection{Dynamiczny wykres}

System ma dynamiczny wykres składający się z dwóch osi: widocznej poziomej, na której znajduje się czas (oś czasu), i niewidocznej pionowej, na której znajduje się liczba 90 dni do sporządzenia raportu i opinii wstępnej. Oznacza to, że sprawy, w których termin na przygotowanie ISR/WO przekracza 90 dni, nie będą widoczne na wykresie. Pojawią się na nim automatycznie, kiedy termin wyniesie 
90 dni. Prostopadle do osi czasu na stałe umieszczona jest pionowa czerwona linia oznaczająca aktualną datę (today). Równolegle do osi poziomej umieszczane są dynamicznie odcinki, których długość wynosi 3 miesiące (to przykładowy czas na wykonanie ISR i WO). Początek każdego odcinka oznaczony kółkiem wypełnionym kolorem niebieskim wyznacza datę, w której rozpoczął bieg termin na sporządzenie ISR i WO. Odcinki znajdujące się ponad osią czasu to sprawy, w których nie upłynął jeszcze czas na sporządzenie ISR i WO. Natomiast odcinki znajdujące się pod osią czasu to sprawy, w których upłynął czas na sporządzenie ISR i WO.

Sprawy najnowsze, czyli te, w których rozpoczął bieg termin na wykonanie ISR, umieszczane są na górze wykresu i z czasem opadają w kierunku osi czasu.

Dane na wykresie aktualizowane są automatycznie przy każdorazowym uruchomieniu programu.

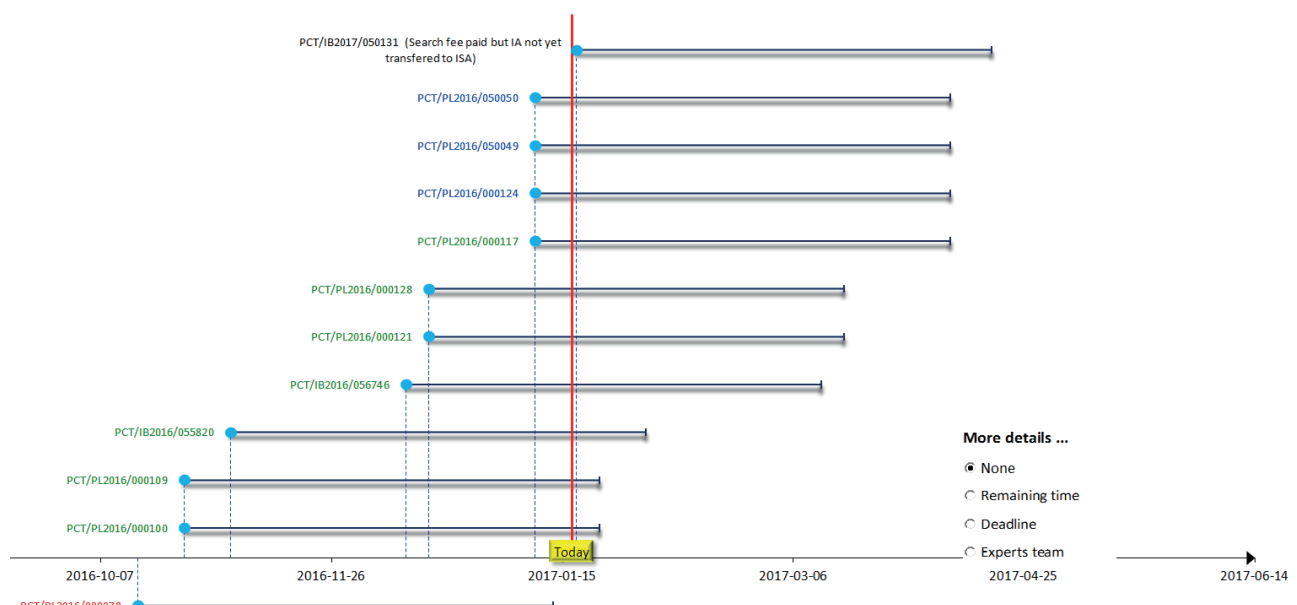

Rys. 4. Dynamiczny wykres z wybraną opcją None

Źródło: opracowanie własne.

Po lewej stronie każdego niebieskiego kółka mogą się znajdować informacje dotyczące numeru sprawy, zespołu ekspertów przydzielonych do wykonania ISR i WO, ostatecznego terminu na wykonanie ISR i WO, czasu pozostałego do wykonania ISR i WO, opóźnień w wykonaniu ISR, WO i informacje o tym, że gdy rozpoczął bieg termin na przygotowanie ISR i WO, ale nie wyznaczono zespołu ekspertów, w zależności od ustawień narzędzia More details.

Gdy w narzędziu More details wybrano opcję None (rys. 4), na wykresie przy każdym kółeczku znajduje się tylko numer zgłoszenia międzynarodowego w trzech różnych kolorach:

c) zielonym, oznaczającym, że w sprawie rozpoczął bieg termin na wykonanie ISR i WO, przydzielono zespół ekspertów i nie upłynął termin na wykonanie ISR i WO, 
d) niebieskim oznaczającym, że w sprawie rozpoczął bieg termin na wykonanie ISR i WO, nie przydzielono jeszcze zespołu ekspertów i nie upłynął termin na wykonanie ISR i WO,

e) czerwonym (dla spraw umieszczonych poniżej osi czasu), oznaczającym, że w sprawie rozpoczął się termin na wykonanie ISR i WO, przydzielono zespół ekspertów i upłynął termin na wykonanie ISR i WO,

f) czarnym (dla spraw umieszczonych w górnej części wykresu), oznaczającym, że sprawa została opłacona, ale nie została przekazana do ISA, w sprawie nie rozpoczął biegu termin na wykonanie ISR/WO nie przydzielono zespołu ekspertów.

Gdy wybrano opcję Remaining time (rys. 5), na wykresie przy każdym kółeczku znajduje się numer zgłoszenia międzynarodowego w czterech różnych kolorach oraz informacja o liczbie dni pozostałych do wykonania ISR i WO (np. pozostało 9 dni na sporządzenie ISR i WO w sprawie PCT/PL2016/000100 - remain 9 days).

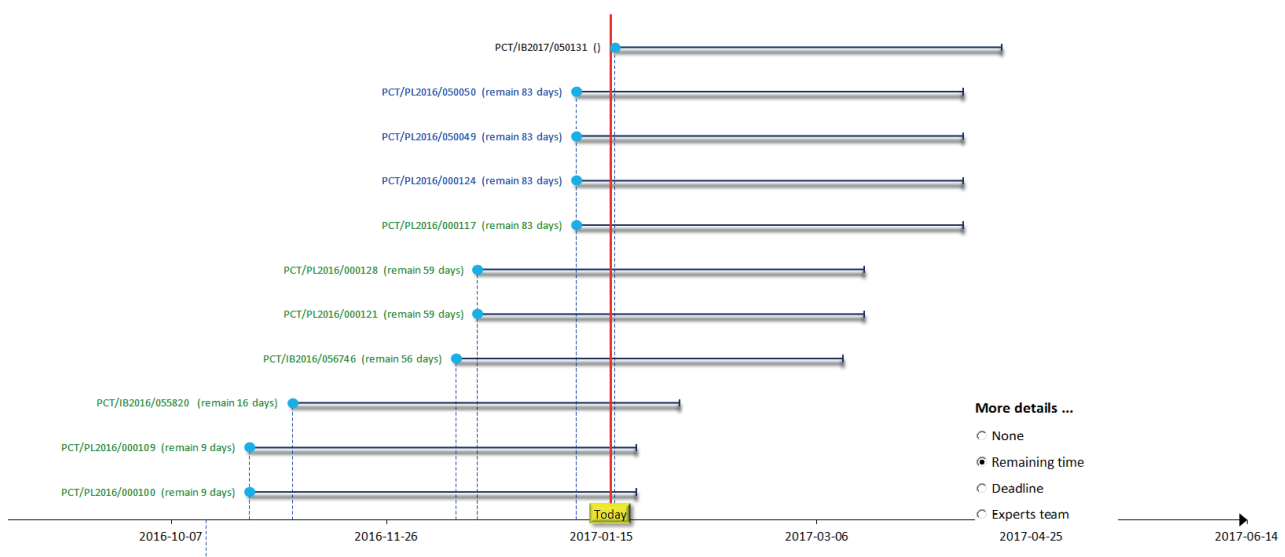

Rys. 5. Dynamiczny wykres z wybraną opcją Remaining time

Źródło: opracowanie własne.

Gdy wybrano opcję Deadline (rys. 6), na wykresie przy każdym kółeczku znajduje się numer zgłoszenia międzynarodowego w czterech różnych kolorach oraz ostateczny termin na wykonanie ISR i WO. Jeśli upłynął termin na wykonanie ISR i WO, numer zgłoszenia i data oznaczone kolorem czerwonym i są przeniesione poniżej osi czasu (sprawa wycofana testowa nr PCT/PL2016/000078).

Jeśli wybrano opcję Experts team (rys. 7), na wykresie przy każdym kółecz$\mathrm{ku}$ znajdują się numer zgłoszenia międzynarodowego w czterech różnych kolorach oraz nazwisko i imię ekspertów przydzielonych do sprawy. Nazwisko i imię umieszczone jako pierwsze oznacza pierwszego eksperta, natomiast drugie oznacza drugiego eksperta. Gdy nie przydzielono zespołu ekspertów, a w sprawie rozpoczął bieg termin na wykonanie ISR i WO, na wykresie pojawia się stosowna informacja (np. drugi ekspert nie został jeszcze przydzielony - not yet designated). Jeśli nie 


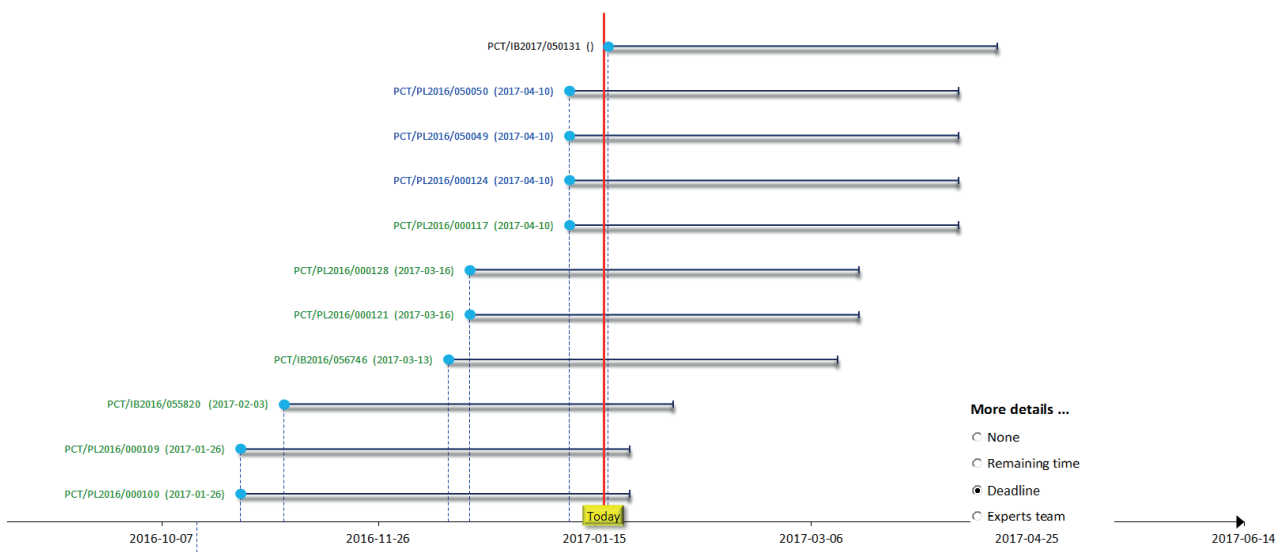

Rys. 6. Dynamiczny wykres z wybraną opcją Deadline

Źródło: opracowanie własne.

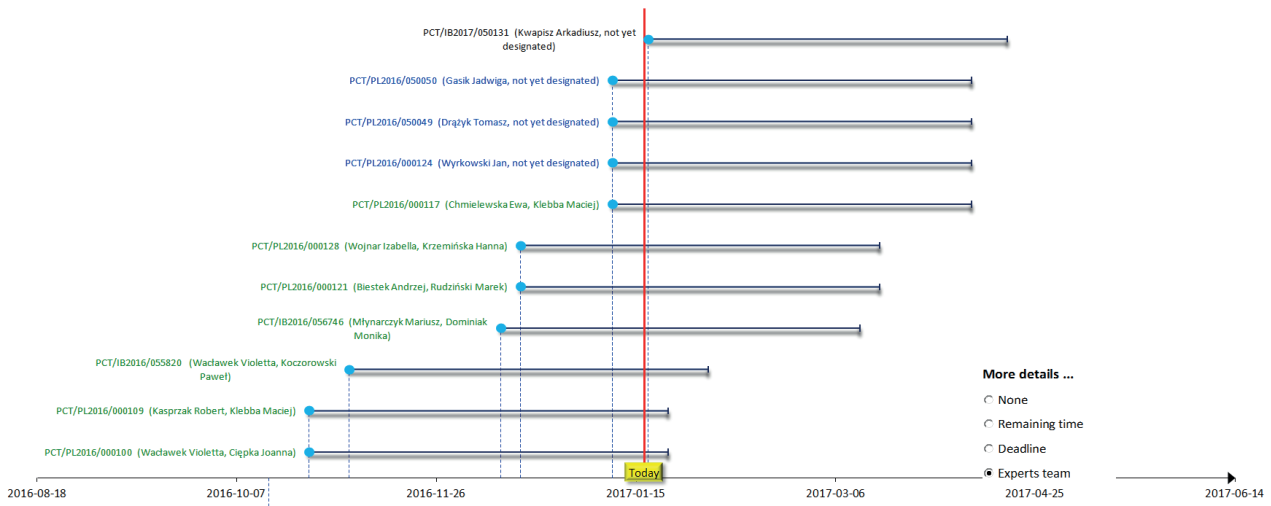

Rys. 7. Dynamiczny wykres z wybraną opcją Experts team

Źródło: opracowanie własne.

przydzielono zespołu ekspertów, a w sprawie (PCT/IB2016/050131) nie rozpoczął biegu termin (niebieskie kółeczko znajduje się po prawej stronie czerwonej linii pionowej) na wykonanie ISR i WO (sprawa nie została przekazana do ISA), na wykresie obok numeru w kolorze czarnym pojawia się stosowna informacja (np. drugi ekspert nie został jeszcze przydzielony - not yet designated).

Program umieszcza na wykresie tylko te sprawy, których termin na wykonanie ISR/WO nie przekracza 90 dni. Pozostałe oczekują w kolejce na pojawienie się na wykresie. Aby zobaczyć ich status, należy skorzystać z interfejsu z narzędziem wyszukiwawczym Select. 
Większość aplikacji do zarządzania dokumentacją prezentuje informacje w postaci tabel z danymi, które są sortowane. Duża liczba danych i kolumn w tabeli jest uciążliwa dla zarządzającego dokumentacją i dla samych użytkowników. Przedstawiony zmodyfikowany wykres Gantta wyróżnia się jasnością przekazu informacji niezbędnych do terminowej realizacji przydzielonych zadań. Już na pierwszy rzut oka można określić, jakie zadanie powinno zostać wykonane w pierwszej kolejności.

\subsection{Moduł Bazy danych}

Moduł bazy danych jest przeznaczony do modyfikowania danych w bazie danych VPI Data. Moduł składa się z trzech zakładek, co oznacza, że uprawniony użytkownik może uzyskać dostęp do zasobów bazy danych VPI (zakładka o nazwie International application action), do statystyk (zakładka o nazwie Statistics) lub do ustawień (zakładka o nazwie Settings). Wprowadzanie danych do bazy danych jest wspomagane interfejsem graficznym, w którym należy wprowadzić odpowiednie dane dla określonego zgłoszenia międzynarodowego. Może on zostać uruchomiony tylko przez użytkownika mającego uprawnienia do modyfikacji bazy danych VPI. W razie braku takich uprawnień pojawi się stosowny komunikat o odmowie dostępu do zasobów VPI Data.

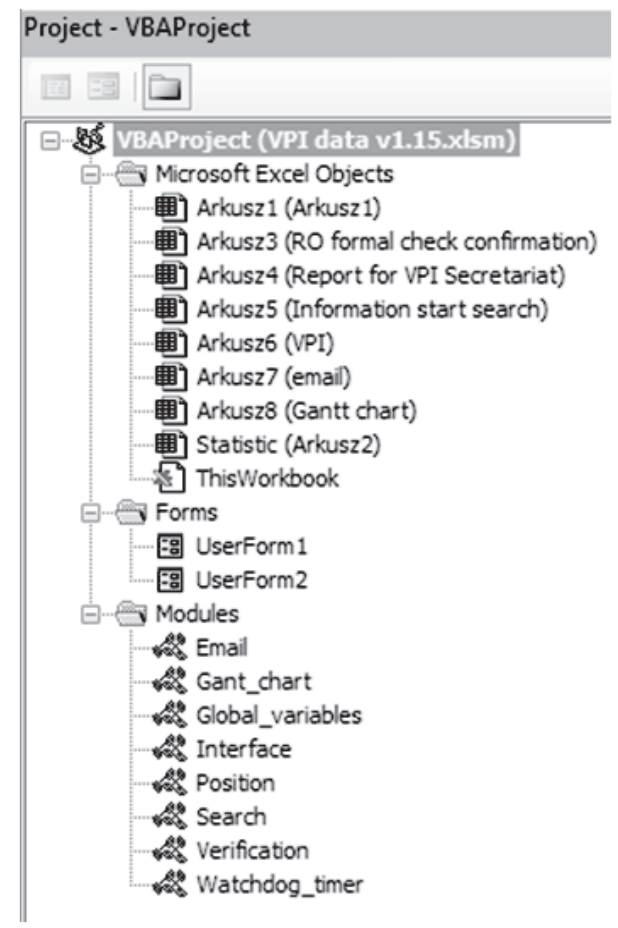

Rys. 8. Struktura aplikacji

Źródło: opracowanie własne. 
Nad wprowadzaniem danych czuwają odpowiednie walidatory, które na bieżąco kontrolują znaki wprowadzane przez użytkownika, dzięki czemu nie ma możliwości wprowadzenia np. niewłaściwego numeru zgłoszenia PCT.

Baza danych składa się z dwóch tabel; są nimi:

1) tabela $z$ listą zgłoszeń patentowych,

2) tabela $\mathrm{z}$ listą ekspertów.

Jest to w pewnym sensie relacyjna baza danych, której mechanizmy łączenia opierają się na SQL. Cały system został przygotowany w Visual Basic; wszystkie przygotowane funkcje zostały umieszczone w następujących modułach: Email, Gant_chart, Global_variables, Interface, Position, Search, Verification, Watchdog timer. Do komunikacji z użytkownikiem służą formularze UserForm1 i UserForm2 (rys. 8).

W arkuszu kalkulacyjnym można znaleźć wiele formuł, które odpowiedzialne są za obliczenia dat i liczbę dni pozostałych do sporządzenia ISR/WO.

\subsection{Kreator XML}

Moduł kreatora XML umożliwia utworzenie pliku eksportu niezbędnego do automatycznego lub ręcznego wygenerowania statystyk z użyciem programu VPI Interactive Chart o nazwie VPI export.xml w określonej lokalizacji.

\section{VPI Interactive Chart}

System VPI Data współpracuje z niezależnym programem o nazwie VPI Interactive Chart w celu przedstawienia statystyk dotyczących zgłoszeń dokonanych w ramach działalności Wyszehradzkiego Instytutu Patentowego. Program dostarcza wiele informacji związanych z liczbą dokonanych zgłoszeń i ich statusu na podstawie danych pobranych z systemu ePCT zarządzanego przez Światową Organizację Własności Intelektualnej (WIPO). Został on przygotowany w środowisku.NET C\#. Moduł zawiera cztery niezależne wykresy:

a) wykres słupkowy pionowy (W1) - przedstawiający liczbę dokonanych zgłoszeń,

b) wykres słupkowy pionowy (W2) - przedstawiający liczbę sporządzonych raportów i opinii pisemnych,

c) wykres kołowy (W3) - przedstawiający status wszystkich zgłoszeń dokonanych w ramach VPI, tj. published, not yet published, published and withdrawn, withdrawn,

d) wykres słupkowy poziomy (W4) - przedstawiający zgłoszenia, którym przydzielono symbol klasyfikacji IPC.

\subsection{Podstawowe funkcjonalności}

Do podstawowych funkcjonalności wykresu należą: zmiana szerokości słupków odpowiednio F11 - do zmniejszenia, F12 - do zwiększenia szerokości słupka oraz 
możliwość przewijania zawartości na wykresie za pomocą poziomego paska przewijania umieszczonego pod wykresem. Kolory słupków są zróżnicowane w zależności od liczby zgłoszeń w danym miesiącu, np. gdy w miesiącu wpłynęły tylko cztery zgłoszenia, słupek jest czerwony, gdy wpłynęło ich więcej, słupek jest pomarańczowy, żółty itp., analogicznie do kolorów widma fal elektromagnetycznych.

Wbudowany moduł zaciągania danych z konwerterem formatu dat (przechwytywanie w locie dat o formacie np. „25 Jan 2017” i zamiana na format „2017-01-25” akceptowalny przez.NET) umożliwia zaciąganie danych z plików.xml,.xls lub.xlsx tuż po uruchomieniu programu. Plik exportu.xls można pobrać bezpośrednio z systemu ePCT. Plik z ePCT powinien mieć nazwę ePCT export.xls, aby moduł zaciągania prawidłowo go rozpoznał i przekonwertował do formatu.xml. Postęp w konwertowaniu danych pobranych z pliku exportu ePCT uwidoczniony jest na pasku postępu, który pojawia się tuż po zaciągnięciu go na aktywne pole wykresu. Czas przetwarzania nie powinien przekroczyć 10 sekund, w zależności od szybkości komputera.

W rezultacie konwersji tworzony jest plik exportu o nazwie ePCT export.xml w określonej lokalizacji. Moduły interpretera badają datę plików eksportu, co oznacza, że gdy pliki będą starsze niż jeden miesiąc, moduł powiadomi o tym użytkownika stosownym komunikatem tuż po uruchomieniu wykresu.

Pole wykresu jest aktywne, co oznacza, że umożliwia realizację funkcji typu drag \&drop. Dane mogą być zaciągnięte na wykres bezpośrednio z pliku, który zostanie przeniesiony na pole wykresu z użyciem myszki.

\section{Niedostatki i plan rozwoju}

Aktualnie system jest tymczasowym narzędziem niezbędnym do zarządzania dokumentacją w VPI. Oznacza to, że ma niedogodności spowalniające prace nad np. aktualizacją danych, które trzeba wprowadzać ręcznie. Dodatkowo wszystkie powiadomienia generowane są przy uruchomieniu aplikacji, co oznacza, że jeśli ekspert jej nie uruchomi, to nie wygeneruje mu komunikatu. Tego typu zadania najczęściej przypisuje się aplikacjom typu usługa, które instaluje się w systemie i które działają niezależnie od tego, czy użytkownik aplikację uruchomił, czy też nie.

W przyszłości kod VPI Data napisany w Visual Basic zostanie przeniesiony na silniejszą platformę, mianowicie.NET C\#.

Jeśli WIPO zdecyduje się zmienić plik eksportu, dostępny w VPI Interactive Chart konwerter plików typu.xls na.xml będzie, po drobnej modyfikacji, integralną częścią VPI Data, co niewątpliwie usprawni cały proces aktualizacji danych.

W efekcie system powinien prowadzić dialog z użytkownikiem i na podstawie jego komend generować przynajmniej częściowo wypełnione dokumenty. 


\section{Podsumowanie i wnioski}

Można wymienić wiele pozytywnych cech wynikających z długotrwałego korzystania z systemu, ale najważniejszą z nich, ze względu na dostępność kodów źródłowych, jest możliwość szybkiego dostosowania go do nowych potrzeb. Dzięki temu innowacyjnemu rozwiązaniu każdy z pracowników Departamentu Badań Patentowych Urzędu Patentowego RP otrzymuje informacje i powiadomienia, co zapewnia terminowość w wykonywaniu przydzielonych mu zadań.

\section{Literatura}

Jasiński A.H., 2006, Innowacje i transfer techniki w procesie transformacji, Difin, Warszawa.

Knosala R., Boratyńska-Sala A., Jurczyk-Bunkowska M., Moczała A., 2014, Zarządzanie innowacja$m i$, PWE, Warszawa.

Łapuńka I. Knosala R., 2010, - Istota zakłóceń w zarządzaniu projektami, Zarządzanie Przedsiębiorstwem, nr 1.

OpenOffice.org 2.0 Calc, Project-Management with Gantt-Charts, first edition, 2005.

Układ o współpracy patentowej PCT sporządzony w Waszyngtonie dnia 19 czerwca $1970 \mathrm{r}$.

Ustawa z dnia 30 czerwca 2000 r. - Prawo własności przemysłowej, Dz.U. 2013, poz. 1410 z późniejszymi zmianami.

Wilson J.M., 2003, Gantt charts: A centenary appreciation, European Journal of Operational Research. 